\section{International Scientific Journal Theoretical \& Applied Science}

p-ISSN: 2308-4944 (print) $\quad$ e-ISSN: 2409-0085 (online)

Year: 2017 Issue: $05 \quad$ Volume: 49

Published: $30.05 .2017 \quad \underline{\text { http://T-Science.org }}$

SECTION 7. Mechanics and machine construction.
Talyat Nuredinovich Azizov

Doctor of Technical Sciences, Professor,

Pavlo Tychyna Uman State Pedagogical University taljat@mail.ru

Alexey Sergeevich Melnyk Candidate of Technical Sciences, assistant professor Pavlo Tychyna Uman State Pedagogical University treklm@mail.ru

Larisa Petrovna Vakal

Candidate of Technical Sciences, Senior Researcher, VM Glushkov Institute of Cybernetics of NAS of

Ukraine

public.icyb@kiev.ua

Anzhelika Alekseevna Kalenchuk-Porkhanova

Candidate of physico-mathematical sciences,

Senior Researcher

VM Glushkov Institute of Cybernetics of NAS of

Ukraine

public.icyb@kiev.ua

Olga Mikhalovna Orlova

teacher

Pavlo Tychyna Uman State Pedagogical University

o_orlova2010@mail.ru

\title{
ACCORDING TO THE CALCULATION OF REINFORCED CONCRETE CEILINGS TAKING INTO ACCOUNT THE CHANGE IN TORSIONAL STIFFNESS OF PREFABRICATED PLATES AGAINST THE FORMATION OF NORMAL CRACKS
}

Abstract: The article shows the influence of torsional rigidity of reinforced concrete elements on the spatial work of bridges, overlappings, building frames and other complex statically indeterminate systems. It is shown that the determination of torsional stiffnesses by the existing methods assumes the obligatory presence of spatial spiral cracks, and torsional stiffness in the presence of normal cracks is not investigated. A method for determining the torsional rigidity of reinforced concrete elements is described in the presence of normal cracks in them. It is shown that this approach allows calculating the torsion of reinforced concrete elements of any cross-section, and also taking into account the nonlinear properties of concrete. The article also describes the use of approximation methods, in particular, the apparatus of the best Chebyshev approximation.

Key words: Torsional stiffness, spiral cracks, reinforced concrete elements, approximation, concrete.

Language: English

Citation: Azizov TN, Melnyk AS, Vakal LP, Kalenchuk-Porkhanova AA, Orlova OM (2017) ACCORDING TO THE CALCULATION OF REINFORCED CONCRETE CEILINGS TAKING INTO ACCOUNT THE CHANGE IN TORSIONAL STIFFNESS OF PREFABRICATED PLATES AGAINST THE FORMATION OF NORMAL CRACKS. ISJ Theoretical \& Applied Science, 05 (49): 180-189.

Soi: http://s-o-i.org/1.1/TAS-05-49-28 Doi: crostef https://dx.doi.org/10.15863/TAS.2017.05.49.28

Introduction.

It is known that the torsional rigidity of their elements exerts a significant influence on the spatial work of the plate-ribbed systems. In reinforced concrete slab-ribbed systems (bridges, ribbed monolithic and prefabricated ceilings), flexural and torsional rigidity is affected by various cracks $[1,2$, $9,10,13,16,20]$.
When local loads are applied to prefabricated or monolithic reinforced concrete floors, cracks may appear in individual beams or slabs, in others they may be absent. In this case, the torsional and flexural rigidity in the beams without cracks and with cracks will differ. It was shown in $[2,16,20]$ that the redistribution of the local load depends in practically the same manner on both the flexural and torsional 
stiffnesses of the individual elements. This dependence is significant. Consequently, the definition of bending and torsion stiffness is an important and urgent task. Despite this, most calculations for the design of various structures, including well-known powerful software complexes, such as Ansys, Nastran, Lira, are carried out without taking into account the change in torsional stiffness resulting from the formation of normal cracks.

The torsional stiffness of individual elements with normal cracks can be taken into account in the program complexes mentioned above, when using volumetric finite elements. However, when calculating, for example, the skeleton of a multistorey building, a bridge structure or an overlap consisting of many elements, modeling

Each element (column, beam, plate, etc.) from volumetric finite elements with the inclusion of reinforcement elements is very, very laborious and practically impracticable.

To date, there is a large number of studies on the flexural rigidity of reinforced concrete elements with cracks and a very small number of studies of the torsional stiffness of such elements. Most of the studies relating to torsion in reinforced concrete are devoted to the study of the strength of such elements. The existing methods for determining torsional stiffness [14, 22, 25, 26] relate mainly to reinforced concrete elements with spiral cracks under the action of torsional bending, although experimental studies have established a significant effect of normal cracks on the torsional stiffness of reinforced concrete elements [9, 13] . In addition, in these works we consider simple types of sections: a rectangle with a symmetric reinforcement, a ring, cylindrical elements. Considering the fact that in practice there are a variety of types of sections: T-waves, I-beams, hollow triangles, box-shaped, etc., some studies have been carried out in this direction at the Odessa State Academy of Construction [3, 5, 21]. However, these works are only at the initial stage of research. The works devoted to the investigation of the torsional stiffness of reinforced concrete elements with normal cracks [3, 5, 19, 21] have an approximate and particular character.

In connection with the foregoing, the purpose of this article is to develop methods for determining the torsional stiffnesses of reinforced concrete elements with normal cracks using algorithms and software complexes for processing and compressing arrays of experimental data by replacing them with a certain analytical expression (approximant) with a small number of coefficient parameters using known approximation methods.

Qualitatively new approach when performing such a replacement is the use of intellectualized methods of approximation of the function by the best Chebyshev (uniform) approximation, which is much more effective and universal than the interpolation and rms approximation methods.

The main advantage of the Chebyshev method of approximation in comparison with other methods of approximation is to ensure the accuracy of the approximation obtained at a certain set of points of the approximation interval at all points of this interval.

The advantages of the Chebyshev approximation allow us to solve with high accuracy not only the obtaining of an approximant and, as a result, the compression with large (several orders of magnitude) data compression coefficients of a discretely given functional dependence (the direct approximation problem), but also the task of restoring the values of the dependence on "unlit" (Inverse approximation problem).

Developed for the first time in the Institute of Cybernetics named after VM. Glushkov Institute of National Academy of Sciences of Ukraine the apparatus of the best Chebyshev approximation has been used for many years to solve a large number of problems and has repeatedly confirmed high efficiency in comparison with other methods of approximation (for more details, see [12c, 12d]).

The article also substantiates the significant influence of the change in the torsional rigidity of the elements of the structure of the overlap on the redistribution of forces in individual elements.

Statement of the problem and the algorithm for its solution. In view of the foregoing, it is important to develop methods for determining torsional rigidity that would have general hypotheses for any type of cross-section, and also include methods for calculating elements with the presence of both spatial and inclined and normal cracks.

Consider a reinforced concrete element with a normal crack, subject to the action of torque (Figure 1). 


\begin{tabular}{|c|c|c|c|c|c|c|}
\hline Impact Factor: & $\begin{array}{l}\text { ISRA (India) } \\
\text { ISI (Dubai, UAE } \\
\text { GIF (Australia) } \\
\text { JIF }\end{array}$ & $\begin{array}{l}=1.344 \\
=0.829 \\
=0.564 \\
=1.500\end{array}$ & $\begin{array}{l}\text { SIS (USA) } \\
\text { PИНЦ (Russia) } \\
\text { ESJI (KZ) } \\
\text { SJIF (Morocco) }\end{array}$ & $\begin{array}{l}=0.912 \\
=0.234 \\
=3.860 \\
=\mathbf{2 . 0 3 1}\end{array}$ & $\begin{array}{l}\text { ICV (Poland) } \\
\text { PIF (India) } \\
\text { IBI (India) }\end{array}$ & $\begin{array}{l}=6.630 \\
=1.940 \\
=4.260\end{array}$ \\
\hline
\end{tabular}

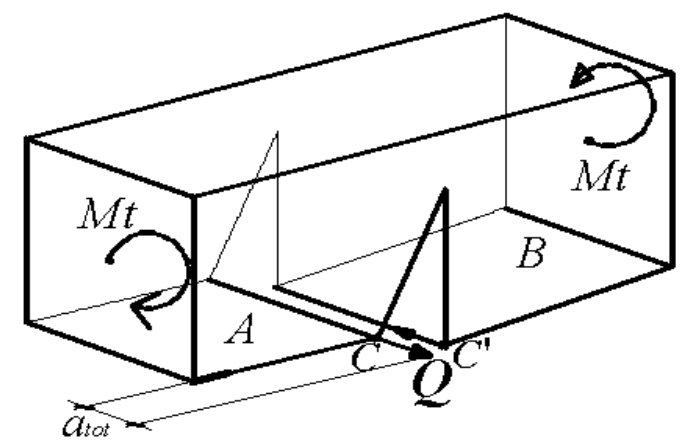

Figure 1 - Scheme of a reinforced concrete element with a normal crack subjected to torsion.

After the mental dissection of the longitudinal reinforcement, the nail strength $\mathrm{Q}$ in it is determined from the compatibility condition of the deformations at the point of dissection of the reinforcement.

Define the deformations of the element in the crack according to the procedure [2]. The discrepancy between the points C and CI (see Figure 1) should be zero at the section of the reinforcement:

$$
\Delta_{C}=\Delta_{M t}-\Delta_{Q}-\Delta_{s m}=0
$$

Where is $\Delta_{M t}$ the divergence of points from the action of the external moment $M_{t} ; \Delta_{Q}$ divergence of points from torsion of the rod by an unknown nagel force Q; $\Delta_{s m}$ - the divergence of points from the crushing of concrete by the nagal force Q. Since the concrete is crumpled in both blocks separated by a crack, the value $\Delta_{s m}$ should be multiplied by 2 . If we denote the discrepancies of the points as a result of the action of the unit nadal force $\bar{Q}=1$ against torsion and on the wrinkling, respectively $\Delta_{Q e d}, \Delta_{s m, e d}$ (1) with the above note in mind $\Delta_{s m}$, we get the value of the nagel force:

$$
Q=\frac{\Delta_{M t}}{\Delta_{Q e d}+2 \cdot \Delta_{s m, e d}}
$$

The components $\Delta_{M t}$ and $\Delta_{Q e d}$ are determined using software packages, as will be discussed below. In this case, use the volumetric finite elements. The component $\Delta_{s m, e d}$ of crushing by a single nagel force $\bar{Q}$ can be determined using empirical data [18]:

$$
\Delta_{s m, e d}=\varphi_{c c}\left(1000 \frac{\bar{Q}^{2}}{d_{s}^{3} E_{b}^{2}}+\frac{\bar{Q}}{d_{s} E_{b}}\right)
$$

Where (3) $\quad \varphi_{c c}=1$ for shortterm load action; ds - is the diameter of the reinforcing bar; $E_{b}$ is the modulus of elasticity of concrete. In expression (3), in contrast to [18], we do not take into account force of pressing a mortgage to the concrete because of its absence. The determination of the amount of displacement from the crushing $\Delta_{\text {sm,ed }}$ can be obtained by any other known theoretical or experimental method. The essence of the calculation does not change from this.

Expression (2) differs from expression (6.59) [2] by the absence of a term containing the displacement from the shear of the reinforcing bar in the fracture. This is done because the displacement from the shear of the reinforcing bar in the fracture turns out to be much smaller (by an order or more) displacement from the crushing of concrete and it can be neglected.

After calculating the unknown value of $Q$, it is easy to determine the total displacement in the fracture $a_{\text {tot }}$ (see Figure 1):

$$
a_{\text {tot }}=2 \cdot \Delta_{\text {sm,ed }} \cdot Q
$$

Further, a coefficient $k_{t}$ is determined, which is the ratio of the deformation of an element with a normal crack to the deformation of an element without cracks:

$$
k_{t}=\frac{a_{t o t}+a_{e}}{a_{e}}
$$

Where $a_{e}$ is the displacement from the torsion of the element without cracks, which is determined by the formula:

$$
a_{e}=R \cdot \varphi_{e}
$$

$R$ is the radius of the turn to the point of definition of displacement (for a rectangular section it is almost half the height of the total cross section of the beam); $\varphi_{e}$ - the angle of rotation of an elastic (without cracks) element length $l_{c r c}$ equal to the distance between cracks, determined by the known formula of the resistance of materials:

$$
\varphi_{e}=\frac{M_{t} \cdot l_{c r c}}{G J_{t}}
$$


Where $G J_{t}$ is the torsional stiffness of the element without cracks.

The value $k_{t}$ is the ratio of the torsional stiffness of the element without cracks to the rigidity of the element with cracks, i.e. How many times the rigidity of an element with normal cracks is less than its initial stiffness. As can be seen from the above formulas, it depends on the distance between the cracks, the diameter of the reinforcement and the depth of the crack (since the values $\Delta_{M t} \Delta_{Q e d}$ of u depend on the latter).

The advantage of the described approach is its generality for calculating the rigidity of elements with normal cracks in any form of cross-section (rectangular, T-shaped, box-like, etc.), because the initial data for the calculation are the values $\Delta_{M t}$ $\Delta_{Q e d}$, determined from the calculation of the FEM.

In this case, the values $\Delta_{M t} \Delta_{Q e d}$, determined once for a particular section and the height of the compressed zone, will allow us to determine the rigidity of an element with different diameters of the reinforcement.

Let us consider in more detail the definition of the quantities $\Delta_{M t} \Delta_{Q e d}$ and the expression (2).

In the works of the authors of $[5,6,7,17]$, a series of studies of the torsional stiffness of reinforced concrete elements of rectangular and Tsections with normal cracks was carried out. In these works it was shown that the main part of the problem of determining the torsional stiffness of a reinforced concrete element with normal cracks is the determination of mutual displacement of the crack edges. This problem can be solved both by an approximate method [6, 19], and using the finite element method. One of the disadvantages of solving this problem, as mentioned above, is the condition of using a large number of volumetric finite elements, which complicates both the creation of the calculation scheme and analysis of the calculation results, especially since this is only part of the solution of the general problem of the stress-strain state Reinforced concrete element with normal cracks in torsion $[5,6,19]$. At the same time, the use of the methods of elasticity theory [7] is probably not possible for all cases of solving the problem $[6,19]$.

One of the methods for solving the problem of determining the displacement of fractured edges during torsion is the method proposed in [4], the use of which can substantially simplify the solution of the engineering problem.

Following [4], it can be assumed that the mutual displacement of the shores of the crack will be a clear function of the height of the compressed zone, the height and width of the beam section and the distance between the cracks, which allows us to apply the methods of approximation to determine this dependence. Let us first consider the dependence of the displacements in a beam of a rectangular crosssection on two parameters-the width $b$ and the section height $\mathrm{h}$-for a fixed value of the distance between the cracks and the height of the zone compressed from the bend. In this case, perhaps not for all cases, it is possible to construct a graph of such a dependence in the form of a certain surface.

Below are examples to explain the derivation of the approximation dependencies.

Example 1. Let there be a beam of a rectangular cross-section made of a material with a modulus of elasticity $\mathrm{Eb}=32500 \mathrm{MPa}$, a shear modulus of $10000 \mathrm{MPa}$. The remaining parameters have

Such values: distance between cracks $l_{c r c}=400$ $\mathrm{mm}$; Height of the compressed zone $x=30 \mathrm{~mm}$, torque $\mathrm{T}=1000 \mathrm{~N} \cdot \mathrm{cm}$.

Approximation of the required surface in the Matlab environment is quite simple. The authors have previously carried out a series of calculations on the FEM using volumetric finite elements. Variable parameters and movements are shown in Table 1.

Table 1

Variable parameters and movements.

\begin{tabular}{|c|c|c|c|c|c|}
\hline № $\mathrm{P} / \mathrm{p}$ & $\begin{array}{l}\text { Dist. Between } \\
\text { cracks. } \\
\boldsymbol{l}_{\text {crc }} \text {, MM }\end{array}$ & $\begin{array}{l}\text { Height of the } \\
\text { compressed zone } \\
x \text {, мM }\end{array}$ & $\boldsymbol{b}, \mathrm{MM}$ & $\boldsymbol{h}, \mathrm{Mм}$ & $\begin{array}{l}\text { Displacement of the crack edges (according } \\
\text { to FEM) } \quad \Delta \cdot 10^{3} \text { (мм) }\end{array}$ \\
\hline 1 & \multirow{8}{*}{400} & \multirow{8}{*}{30} & 60 & 100 & 3.104 \\
\hline 2 & & & 80 & 100 & 1.668 \\
\hline 3 & & & 100 & 100 & 1.043 \\
\hline 4 & & & 60 & 180 & 7.614 \\
\hline 5 & & & 80 & 180 & 3.879 \\
\hline 6 & & & 100 & 180 & 2.305 \\
\hline 7 & & & 160 & 180 & 0.769 \\
\hline 8 & & & 180 & 180 & 0.585 \\
\hline
\end{tabular}




\begin{tabular}{|c|c|c|c|c|c|c|}
\hline Impact Factor: & $\begin{array}{l}\text { ISRA (India) } \\
\text { ISI (Dubai, UAF } \\
\text { GIF (Australia) } \\
\text { JIF }\end{array}$ & $\begin{array}{l}=1.344 \\
=0.829 \\
=0.564 \\
=1.500\end{array}$ & $\begin{array}{l}\text { SIS (USA) } \\
\text { PИНЦ (Russia) } \\
\text { ESJI (KZ) } \\
\text { SJIF (Morocco) }\end{array}$ & $\begin{array}{l}=0.912 \\
=0.234 \\
=3.860 \\
=\mathbf{2 . 0 3 1}\end{array}$ & $\begin{array}{l}\text { ICV (Poland) } \\
\text { PIF (India) } \\
\text { IBI (India) }\end{array}$ & $\begin{array}{l}=6.630 \\
=1.940 \\
=4.260\end{array}$ \\
\hline
\end{tabular}

As a result of processing the initial data in the Matlab environment, the approximate surface shown

in Fig. 2.

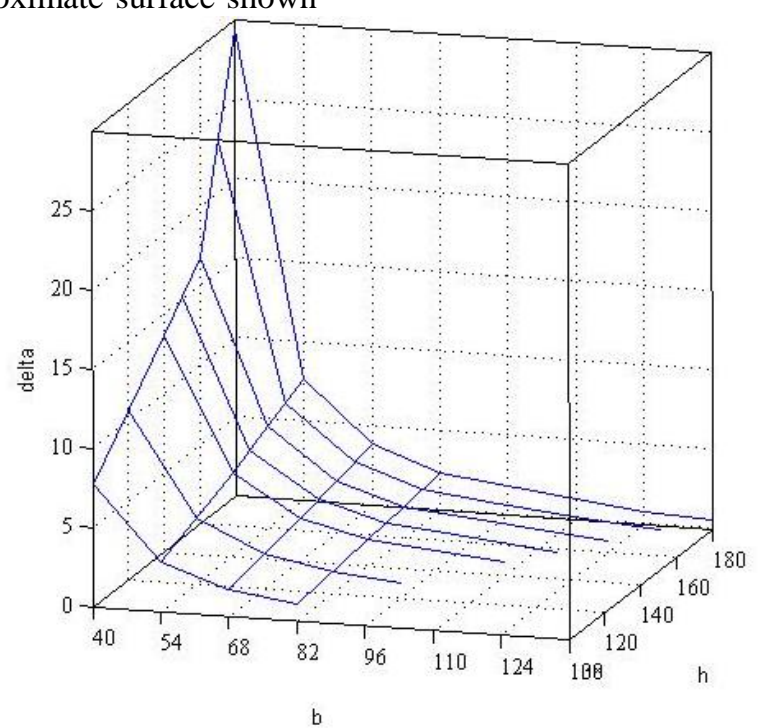

Figure 2 - The dependence of the displacement of the crack banks (delta) on Width (b) and height (h) of the beam section.

To compare the displacements obtained as a result of the approximation with the displacements obtained directly from the calculations using the Lira program using volumetric finite elements, table 2 is compiled. In column 6 of the table, the values of the displacements obtained by the FEC (the Lira program) are given. In column 7 - the displacements obtained on the basis of approximation in the Matlab environment. As can be seen from the table, the values in columns 6 and 7 coincide with a sufficiently high accuracy, which confirms the correctness of the adopted approach to the solution of the problem.

Table 2

Comparison of displacements of crack banks obtained by the Lira program using volumetric finite elements and the approximation method.

\begin{tabular}{|c|c|c|c|c|c|c|c|}
\hline \multirow{2}{*}{ № $\mathrm{P} / \mathrm{p}$} & \multirow{2}{*}{$\begin{array}{l}\text { Dist. Between } \\
\text { cracksl } l_{c r c}(\mathrm{MM})\end{array}$} & \multirow{2}{*}{$\begin{array}{l}\text { Height of the } \\
\text { compressed } \\
\text { zone } \\
x(\mathrm{MM})\end{array}$} & \multirow{2}{*}{$\boldsymbol{b}(\mathrm{MM})$} & \multirow{2}{*}{$\boldsymbol{h},($ мм) } & \multicolumn{2}{|c|}{$\begin{array}{l}\text { Displacement } \\
\Delta \cdot 10^{3}(\mathrm{MM})\end{array}$} & \multirow{2}{*}{ Error $(\%)$} \\
\hline & & & & & MCE & $\begin{array}{l}\text { Approxi } \\
\text { mation }\end{array}$ & \\
\hline 1 & 2 & 3 & 4 & 5 & 6 & 7 & 8 \\
\hline 1 & \multirow{13}{*}{400} & \multirow{13}{*}{30} & 60 & 140 & 5.2469 & 5.3575 & 2.11 \\
\hline 2 & & & 80 & 140 & 2.72018 & 2.7735 & 1.96 \\
\hline 3 & & & 100 & 140 & 1.641188 & 1.6743 & 2.02 \\
\hline 4 & & & 140 & 140 & 0.770339 & 0.8139 & 5.65 \\
\hline 5 & & & 60 & 160 & 6.40637 & 6.4858 & 1.24 \\
\hline 6 & & & 80 & 160 & 3.288858 & 3.3262 & 1.14 \\
\hline 7 & & & 100 & 160 & 1.96683 & 1.9898 & 1.17 \\
\hline 8 & & & 160 & 160 & 0.688064 & 0.6992 & 1.62 \\
\hline 9 & & & 120 & 120 & 0.89508 & 0.90685 & 1.31 \\
\hline 10 & & & 90 & 130 & 1.87789 & 1.8287 & 2.62 \\
\hline 11 & & & 90 & 150 & 2.292 & 2.263 & 1.29 \\
\hline 12 & & & 130 & 150 & 0.99102 & 1.0638 & 7.34 \\
\hline 13 & & & 150 & 150 & 0.71663 & 0.7994 & 11.55 \\
\hline
\end{tabular}

A similar approach is fairly simple to apply for elements with any other shape of sections (T-shaped, I-beams, box-like, etc.), and also with inclined cracks. The number of variables for the approximation can be different. 


\begin{tabular}{|c|c|c|c|c|c|c|}
\hline Impact Factor: & $\begin{array}{l}\text { ISRA (India) } \\
\text { ISI (Dubai, UAF } \\
\text { GIF (Australia) } \\
\text { JIF }\end{array}$ & $\begin{array}{l}=1.344 \\
=0.829 \\
=0.564 \\
=1.500\end{array}$ & $\begin{array}{l}\text { SIS (USA) } \\
\text { PИНЦ (Russia) } \\
\text { ESJI (KZ) } \\
\text { SJIF (Morocco) }\end{array}$ & $\begin{array}{l}=0.912 \\
=0.234 \\
=3.860 \\
=\mathbf{2 . 0 3 1}\end{array}$ & $\begin{array}{l}\text { ICV (Poland) } \\
\text { PIF (India) } \\
\text { IBI (India) }\end{array}$ & $\begin{array}{l}=6.630 \\
=1.940 \\
=4.260\end{array}$ \\
\hline
\end{tabular}

Creating a library of function approximants (similar to Table 2, Figure 2) will greatly simplify the solution of many problems of determining the stiffness parameters of reinforced concrete elements with cracks that can enter as a separate block into existing software systems.

When determining the stiffness parameters of a reinforced concrete element with normal (or inclined) torsion cracks, to determine the movements of any points, it is necessary to compile approximate expressions (based on a certain number of calculations using MCEs), in which the crosssectional dimensions $b$ and $h$, the height of the compressed zone (The height of the zone through which the torque is transmitted), as well as the length of the block separated by normal cracks, the angle of the fracture (in the case of inclined cracks), etc.

For more complex sections, the number of variable parameters will be larger. For example, when the height of the compressed zone is within the edge of the reinforced concrete element of the Isection (Figure 3), the displacement of the crack sides (the angle of mutual rotation of the two blocks separated by a normal crack) will be a function of seven variables:

$$
\Delta_{c r c}=f\left(b_{1}, h_{1}, b_{2}, h_{2}, t, h, x\right) .
$$

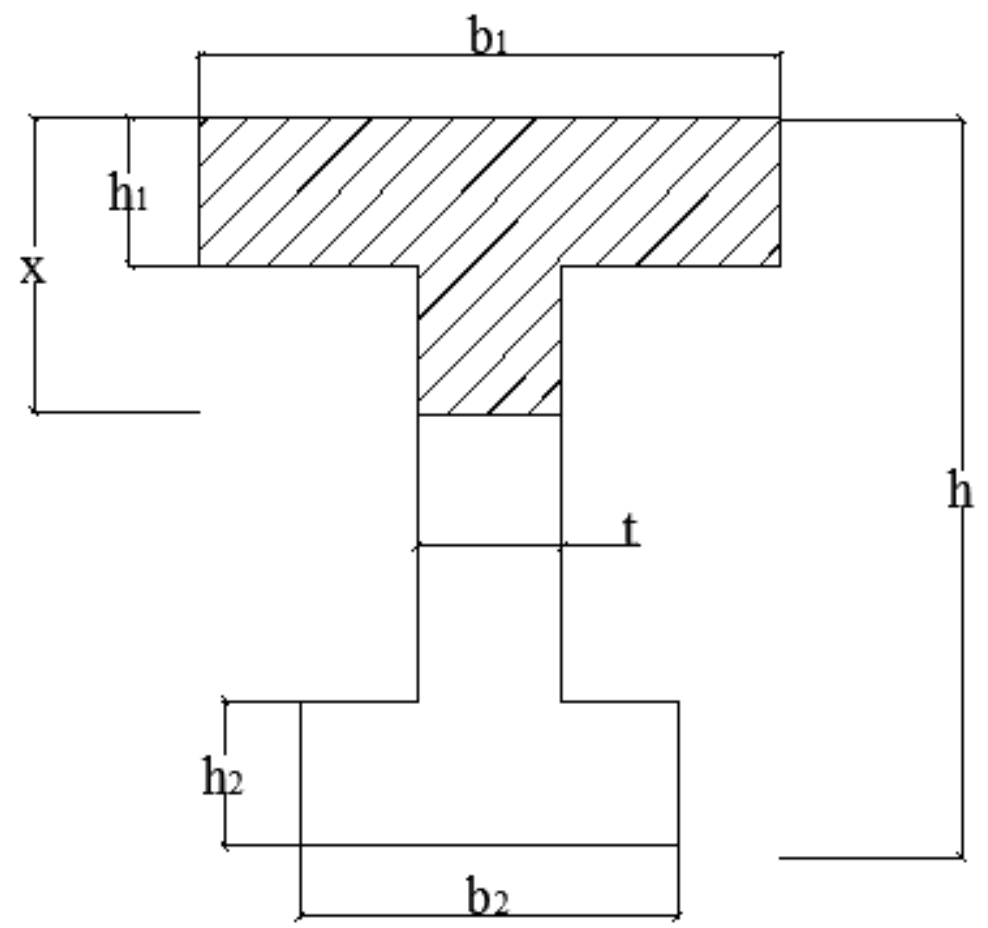

Figure 3 - Scheme to determine the parameters of the approximant for a reinforced concrete I-section with a normal crack.

To approximate such functions of several variables, one can use a software implementation of one of the algorithms of the apparatus of the best Chebyshev approximation, described in $[12 \mathrm{a}, 12 \mathrm{~b}$, $12 \mathrm{c}, 12 \mathrm{~d}]$.

It should be noted that the database of values of these parameters of approximants can be obtained for specific values of the elastic modulus $\mathrm{E}$ and the shear modulus $\mathrm{G}$ of concrete. Taking into account that this problem is linear, to obtain displacements in an element with other values of elasticity and shear module, it is easy to multiply them by the ratio of the corresponding values of the parameters of the considered construction (or the corresponding iteration stage) and the values of the parameters given in the database.

Example 2. Consider the concrete case of calculating the torsional stiffness of hollow-core slabs according to the proposed technique. The section of a hollow-core plate can be represented with sufficient accuracy in the form shown in Fig. 4. 


\begin{tabular}{|c|c|c|c|c|c|c|}
\hline Impact Factor: & $\begin{array}{l}\text { ISRA (India) } \\
\text { ISI (Dubai, UAE } \\
\text { GIF (Australia) } \\
\text { JIF }\end{array}$ & $\begin{array}{l}=1.344 \\
=0.829 \\
=0.564 \\
=1.500\end{array}$ & $\begin{array}{l}\text { SIS (USA) } \\
\text { PИНЦ (Russia) } \\
\text { ESJI (KZ) } \\
\text { SJIF (Morocco) }\end{array}$ & $\begin{array}{l}=0.912 \\
=0.234 \\
=3.860 \\
=\mathbf{2 . 0 3 1}\end{array}$ & $\begin{array}{l}\text { ICV (Poland) } \\
\text { PIF (India) } \\
\text { IBI (India) }\end{array}$ & $\begin{array}{l}=6.630 \\
=1.940 \\
=4.260\end{array}$ \\
\hline
\end{tabular}

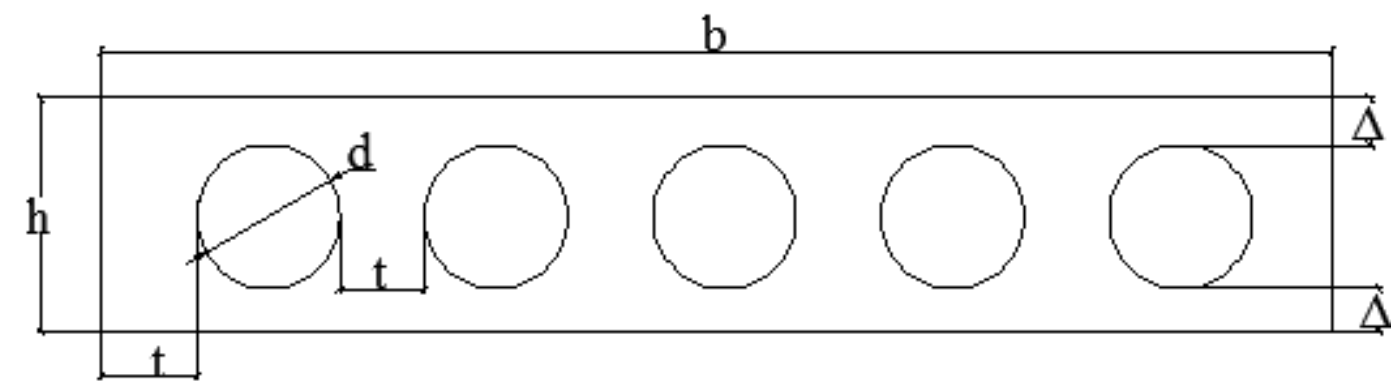

Figure 4 - Scheme to determine the approximation parameters for a hollow-core plate with a normal crack.

The function of mutual displacement of the crack banks in this case will have the form:

$$
\Delta_{c r c}=f(b, h, d, t, \Delta, n) \text {, }
$$

Where $\mathrm{n}$ is the number of voids; The remaining notations are shown in Fig. 4.

In order to approximate the numerical experiment data in this case, it is effective to use the apparatus of the best uniform (Chebyshev) approximation using generalized polynomials [12a, $12 \mathrm{~b}, 12 \mathrm{c}, 12 \mathrm{~d}]$. Thus, for example, using this apparatus for a T-element with a width of the upper flange b1, its thickness $h 1$, the width of the edge b2, the height of the edge $\mathrm{h} 2$, based on a series of Lira calculations using volumetric finite elements, the result of a numerical experiment for the angle of mutual Rotation $\varphi$ of two blocks separated by a normal crack in the form:

$$
\varphi=\frac{-0,00011792 b_{1} h_{1}+0,1886524}{b_{2} h_{2}+16,95905}
$$

Formula (10) makes it possible to calculate the angle of mutual rotation of the crack edges for any values of the geometric parameters of the T-element. It should be noted that this formula was obtained on the basis of data from a numerical experiment with varying the geometric data of the T-section at a specific height of the compressed zone (in this case it is the thickness of the shelf of the brand). If the height of the compressed zone also needs to change, then the rotation angle function $\varphi$ will contain not four variables (as in formula (10)), but five, including the height of the compressed zone (the zone through which torque is transmitted from block to block). But in any case, once obtained (although based on a fairly complex set of data from a numerical experiment), this function can be used in the design practice as many times as you like.

It should be noted that the advantages of the above method of determining the torsional stiffness by creating a database of values of the parameters of the approximants is also that it allows to take into account the nonlinear properties of concrete. Taking into account that the calculation taking into account the nonlinear properties of materials is carried out with the help of iterations, then at each step of iterations new deformation characteristics should be adopted. In the database, the mutual displacement of the shores of the normal crack is a function of the geometric parameters and the height of the zone compressed from the bending (normal crack height) of the expression (8) obtained for specific fixed values of the elastic modulus $\mathrm{E}$ and the shear modulus $\mathrm{G}$ of the concrete. Therefore, having experimental data of these parameters for a particular case under consideration, at each step of the iteration we use an expression of the type (8) with correction for the value of the elasticity and shear module at the current iteration to these parameters accepted in the database.

As for the experimental data on the modulus of elastic modulus of concrete, there are quite a large number of them in the literature. In contrast, experimental data on the nonlinear change in the modulus of shear of concrete were apparently first obtained under the guidance of the author of the article [8]. In these works, an experimentally grounded diagram of concrete displacement having a small section of the descending branch was proposed. Data on nonlinear deformation by torsion are also given in [23, 24, 27].

Thus, we can conclude that, having an apparatus for determining the torsional stiffness of a reinforced concrete element with normal cracks, taking into account the nonlinear properties of concrete, introducing it as one calculation block into the program complexes mentioned above, we can calculate the complex multiple-statically indeterminate systems (overlaps, Bridges, building frames, etc.), taking into account the effect of torsional stiffness on the redistribution of forces between individual elements of the system.

Example 3. Consider the importance of taking into account the change in the torsional stiffness of a rectangular section element depending on the height of the zone without cracks (the height of the compressed zone for the beam element) and the diameter of the longitudinal reinforcement. Table 3 shows the values $k_{t}$ for different variants of a rectangular section element with the following initial data: $E_{b}=25000 \mathrm{MPa} ; \mathrm{G}=10000 \mathrm{MPa} ; b=125$ $\mathrm{mm} ; h=250 \mathrm{~mm} ; M_{t}=10 \mathrm{kN} * \mathrm{~cm} ; L_{c r c}=500$ 


\section{Impact Factor:}

\begin{tabular}{|c|c|c|}
\hline ISRA (India) & $=1.3 \mathrm{z}$ & SIS (USA) \\
\hline ubai, UAF & & РИНЦ $($ Russia $)=\mathbf{0 . 2 3 4}$ \\
\hline Australia) & & ESJI (KZ) \\
\hline JIF & $=1.500$ & SJIF $($ Morocco $)=\mathbf{2 . 0}$ \\
\hline
\end{tabular}

mm. The data of the table are obtained by N.M. Sribnjak by an approximate method [19].

As can be seen from Table. 3, the torsional stiffness of an element with normal cracks can be much less than the rigidity of an element without cracks, and it depends both on the distance between the cracks, the height of the zone without cracks, and on the diameter of the longitudinal reinforcement.

Changing the torsional rigidity of a reinforced concrete element with normal cracks as a function of the diameter of the reinforcement and the height of the cracks.

\begin{tabular}{|c|c|c|c|c|c|}
\hline$L_{c r c}(\mathrm{MM})$ & $\mathrm{X}($ мM) & $\mathrm{d}_{\mathrm{s}}(\mathrm{MM})$ & $\Delta_{M_{t}}\left(\mathrm{MM}^{*} 100\right)$ & $\Delta_{Q e d}\left(\right.$ MM $\left.^{*} 10000\right)$ & $k_{t}$ \\
\hline 500 & 25 & 0.8 & 2.766 & 7.178 & 1.63 \\
\hline 500 & 25 & 1.2 & 2.766 & 7.178 & 1.44 \\
\hline 500 & 25 & 1.8 & 2.766 & 7.178 & 1.3 \\
\hline 500 & 50 & 0.8 & 1.512 & 4.027 & 1.56 \\
\hline 500 & 50 & 1.2 & 1.512 & 4.027 & 1.4 \\
\hline 500 & 50 & 1.8 & 1.512 & 4.027 & 1.28 \\
\hline 500 & 75 & 0.8 & 0.926 & 2.580 & 1.48 \\
\hline 500 & 75 & 1.2 & 0.926 & 2.580 & 1.36 \\
\hline 500 & 75 & 1.8 & 0.926 & 2.580 & 1.25 \\
\hline 250 & 25 & 0.8 & 2.766 & 7.178 & 2.27 \\
\hline 250 & 25 & 1.2 & 2.766 & 7.178 & 1.88 \\
\hline 250 & 25 & 1.8 & 2.766 & 7.178 & 1.6 \\
\hline
\end{tabular}

After determining the nagel force in the longitudinal reinforcement and the rigidity of the reinforced concrete element with normal torsional fractures, it is easy to determine the concrete strength of the zone compressed from bending from the action of torque by the method [3].

Example 4. Let us now consider the effect of torsional stiffnesses on the spatial work of bridges and overlaps. Modern methods for calculating the reinforced concrete structures of bridges and overlaps take into account the change in flexural stiffnesses in the course of cracking. Alteration of the torsional rigidities is almost not paid attention. This is due, first of all, to a very small study of this issue, although, as mentioned above, consideration of this factor is essential for the redistribution of effort between the elements of bridge structures and overlaps. Consider, for example, a ribbed system with a span of $5000 \mathrm{~mm}$ with five ribs $250 \times 250 \mathrm{~mm}$ when the middle (third) rib is loaded with a uniformly distributed load $\mathrm{q}=10 \mathrm{kN} / \mathrm{m}$. The thickness of the shelves connecting the ribs is 50 $\mathrm{mm}$. Suppose that the shelves are connected to the ribs at the level of the centers of gravity of the latter, as well as the hinged connection of the shelves (imitation of the assembled ribbed system). Table 4 shows the values for five different versions of the torsional stiffness of the first three ribs (from left to right) of such a ribbed system. The calculations were made by the method of [2]. To the right of the value of the bending moments, errors are given with respect to the basic version, in which the same torsional stiffness of all ribs of the ribbed system is provided.

Table 4

Comparison of bending moments $[\mathrm{kN} \cdot \mathrm{m}]$ in the ribs of a ribbed system when the torsional stiffness of individual ribs changes

\begin{tabular}{|l|l|l|l|l|l|l|l|}
\hline № & \multicolumn{2}{|c|}{ Ribber stiffness values } & \multicolumn{2}{c|}{$M_{1, \max }$} & \multicolumn{2}{c|}{$M_{2, \max }$} & \multicolumn{2}{c|}{$M_{3, \max }$} \\
\cline { 3 - 7 } & value & $\varepsilon, \%$ & value & $\varepsilon, \%$ & value & $\varepsilon, \%$ \\
\hline & $\begin{array}{l}\text { All edges of the same section } \\
\text { (base version) }\end{array}$ & 3,194 & 0 & 6,688 & 0 & 11,498 & 0 \\
\hline $\begin{array}{l}\text { The first rib has a torsional rigidity } \\
\text { of 2 times less }\end{array}$ & 3,015 & 6 & 6,802 & 1,7 & 11,540 & 0,3 \\
\hline 3 & $\begin{array}{l}\text { The first rib has a torsional } \\
\text { stiffness of 4 times less }\end{array}$ & 2,711 & 18 & 6,995 & 4,5 & 11,611 & 1 \\
\hline 4 & $\begin{array}{l}\text { The second rib has a torsional } \\
\text { stiffness of 4 times less }\end{array}$ & 1,085 & 294 & 6,486 & 3,1 & 12,978 & 12,8 \\
\hline 5 & $\begin{array}{l}\text { The second and fourth ribs have a } \\
\text { torsional stiffness of 4 times less }\end{array}$ & 1,184 & 269 & 7,083 & 5,9 & 14,729 & 28,1 \\
\hline
\end{tabular}




\begin{tabular}{|c|c|c|c|c|c|c|}
\hline Impact Factor: & $\begin{array}{l}\text { ISRA (India) } \\
\text { ISI (Dubai, UAF } \\
\text { GIF (Australia) } \\
\text { JIF }\end{array}$ & $\begin{array}{l}=1.344 \\
=0.829 \\
=0.564 \\
=1.500\end{array}$ & $\begin{array}{l}\text { SIS (USA) } \\
\text { PИНЦ (Russia) } \\
\text { ESJI (KZ) } \\
\text { SJIF (Morocco) }\end{array}$ & $\begin{array}{l}=0.912 \\
=0.234 \\
=\mathbf{3 . 8 6 0} \\
=\mathbf{2 . 0 3 1}\end{array}$ & $\begin{array}{l}\text { ICV (Poland) } \\
\text { PIF (India) } \\
\text { IBI (India) }\end{array}$ & $\begin{array}{l}=6.630 \\
=1.940 \\
=4.260\end{array}$ \\
\hline
\end{tabular}

It follows from the table that when the torsional stiffness of one rib is reduced by a factor of 4 (which is quite possible in real reinforced concrete beams), bending moments can vary several times (!), Which imposes a significant imprint on the stress-strain state of the beam and system in question Whole. Thus, this simple example shows how important it is to take into account the change in torsional rigidity in the beams of bridges and overlapping when normal cracks form in them.

In spite of the fact that to approximate functions f of type (8) or (9) it is necessary to carry out a sufficiently large but finite number of calculations using software complexes in which the finite element method with the use of volumetric finite elements is realized, which may seem complicated, the advantage of such Approach is obvious, because Once obtained, such dependencies can be used as many times as necessary by designers and engineers to solve specific problems in the manner described above.

Creating a library of approximants will greatly simplify the solution of many complex problems, where the number of such elements would be much smaller than the number of finite elements using the traditional finite element method.

Conclusions and prospects of research. A new approach to the determination of torsional stiffnesses of reinforced concrete elements with cracks is proposed, which allows solving torsion problems of reinforced concrete elements of any cross-section using methods for approximating the displacement functions at the crack location obtained from solving a number of problems using the finite element method. It should be noted that the use of the best Chebyshev approximation in this apparatus makes it possible to improve significantly the efficiency of solving problems. Also the significant effect of torsional stiffnesses on the spatial work of bridge elements and overlapping under the action of local band loads is shown.

In the long term, it is proposed to define functions of the type (8) or (9) for solving the problems of reinforced concrete elements torsion of different cross sections and their various sizes, as well as extending the proposed approach for the calculation taking into account the nonlinear properties of reinforced concrete.

\section{References:}

1. Azizov TN (2009) Zhestkost' zhelezobetonnykh elementov pri kruchenii i ee vliyanie na prostranstvennuyu rabotu mostov // Mekhanika i fizika ruynuvannya budivel'nikh materialiv ta konstruktsiy// Zbirnik naukovikh prats'. NAN Ukraïni. Fiziko-mekh.institut im.. V.G. Karpenka. - L'viv. - p. 576-590.

2. Azizov TN (2006) Prostranstvennaya rabota zhelezobetonnykh perekrytiy. Teoriya i metody rascheta: Diss. ... dokt. tekhn. nauk: 05.23.01/ Poltavskiy natsional'nyy tekhnicheskiy universitet. - Poltava. - 406 p.

3. Azizov TN, Sribnyak NN (2008) Prochnost' pri kruchenii zhelezobetonnykh elementov pryamougol'nogo secheniya s normal'nymi treshchinami//Resursoekonomni materiali, konstruktsiï, budivli ta sporudi. Vip. 17., Rivne: Nats. un-t vodnogo gospodarstva ta prirodokoristuvannya. - p. 100-104.

4. Azizov, TN (2010) Ispol'zovanie approksimatsionnykh konechnykh elementov $\mathrm{v}$ raschetakh konstruktsiy / T.N. Azizov // Visnik Odes'koï derzhavnoï akademiï budivnitstva ta arkhitekturi. - № 39, chastina 1. - p. 4-9.
5. Azizov TN (2009) Krutil'naya zhestkost' tavrovykh zhelezobetonnykh elementov $\mathrm{s}$ normal'nymi treshchinami / T.N. Azizov, V.I. Stadnik // Visnik Odes'koï derzhavnoï akademiï budivnitstva ta arkhitekturi. - № 33 - p. 4-11.

6. Azizov TN (2007) Opredelenie krutil'noy zhestkosti zhelezobetonnykh elementov $\mathrm{s}$ treshchinami / T.N. Azizov // Dorogi i mosti. Zbirnik naukovikh prats'. K.: DerzhdorNDI. Vip. 7. Tom 1. - p. 3-8.

7. Arutyunyan NK (1963) Kruchenie uprugikh tel. / N.Kh. Arutyunyan, B.L. Abramyan; - M.: Fizmatgiz. -688 p.

8. Vil'danova NR (2013) Modul' zsuvu betonu z krakhuvannyam deformatsiy plastichnosti i yogo vpliv na krutil'nu zhorstkist' zalizobetonnikh elementiv: Dis. ... kand. tekhn. nauk: 05.23.01 / Odes'ka derzhavna akademiya budivnitstva ta arkhitekturi. - Odesa. $-187 \mathrm{p}$.

9. Gornov VN (1950) Issledovanie prochnosti i zhestkosti sbornykh zhelezobetonnykh perekrytiy iz lotkovykh nastilov // Materialy i konstruktsii v sovremennoy arkhitekture. - M.: Stroyizdat. 


\begin{tabular}{|c|c|c|c|c|c|c|}
\hline Impact Factor: & $\begin{array}{l}\text { ISRA (India) } \\
\text { ISI (Dubai, UAE } \\
\text { GIF (Australia) } \\
\text { JIF }\end{array}$ & $\begin{array}{l}=1.344 \\
=0.829 \\
=0.564 \\
=1.500\end{array}$ & $\begin{array}{l}\text { SIS (USA) } \\
\text { PИНЦ (Russia } \\
\text { ESJI (KZ) } \\
\text { SJIF (Morocco }\end{array}$ & $\begin{array}{r}=\mathbf{0 . 9 1 2} \\
=\mathbf{0 . 2 3 4} \\
=\mathbf{3 . 8 6 0} \\
=\mathbf{2 . 0 3 1}\end{array}$ & $\begin{array}{l}\text { ICV (Poland) } \\
\text { PIF (India) } \\
\text { IBI (India) }\end{array}$ & $\begin{array}{l}=6.630 \\
=1.940 \\
=4.260\end{array}$ \\
\hline
\end{tabular}

10. Drozdov PF (1977) Konstruirovanie i raschet nesushchikh sistem mnogoetazhnykh zdaniy i ikh elementov. - M.: Stroyizdat. - 223 p.

11. Zalesov AS, Klimov YA (1989) Prochnost' zhelezobetonnykh konstruktsiy pri deystvii poperechnykh sil. - Kiev: Budivel'nik. -105 p.

12. Kalenchuk-Porkhanova AA (2008) Paket programm approksimatsii funktsiy / A.A. Kalenchuk-Porkhanova, L.P. Vakal // Komp’yuterni zasobi, merezhi ta sistemi. - № 7. - p. 32-38.

13. Vakal LP (2017) Matematichni mashini ta sistemi. - №1. - p. 90-96.

14. Kalenchuk-Porkhanova AA (2009) Nailuchshaya chebyshovskaya approsimatsiya funktsiy odnoy i mnogikh peremennykh // Kibernetika i sistemnyy analiz. - №6. - p.155164.

15. Kalenchuk-Porkhanova AA, Vakal LP (2009) Nailuchshaya chebyshovskaya approsimatsiya dlya szhatiya chislennoy informatsii // Komp'yuternaya matematika. - №1. - p.111119.

16. Karabanov BV (2001) Nelineynyy raschet sborno-monolitnykh zhelezobetonnykh perekrytiy // Beton i zhelezobeton. - №6. - p. 14-18.

17. Karpenko NI (1976) Teoriya deformirovaniya zhelezobetona s treshchinami. / N.I. Karpenko; - M.: Stroyizdat. - 208 p.

18. Kouen GD (1972) Kruchenie v obychnom i predvaritel'no napryazhennom zhelezobetone: Per. s angl. / G.Dzh. Kouen; - M.: Izd-vo literatury po stroitel'stvu. $-104 \mathrm{p}$.

19. Lantukh-Lyashchenko AI (1992) Razvitie diskretno-kontinual'nykh metodov rascheta kombinirovannykh sistem: Avtoref. diss. .. dokt. tekhn. nauk: 05.23.17/ KISI. - K., -30 p.

20. Mel'nik OS (2013) Zhorstkist' ta mitsnist' zalizobetonnikh elementiv porozhnistogo trikutnogo pererizu $\mathrm{z}$ normal'nimi trishchinami pri kruchenni: Dis. ... kand. tekhn. nauk: 05.23.01 / Odes'ka derzhavna akademiya budivnitstva ta arkhitekturi. - Odesa. - 187 p.

21. (1984) Rekomendatsii po proektirovaniyu stal'nykh zakladnykh detaley dlya zhelezobetonnykh konstruktsiy / NIIZhB. -M.: Stroyizdat, $-87 \mathrm{p}$.

22. Sribnyak NM (2009) Krutil'na zhorstkist' zalizobetonnikh elementiv perekrittiv $\mathrm{Z}$ normal'nimi trishchinami: avtoref. dis. .... kand. tekhn. nauk 05.23.01 / Sribnyak Nataliya Mikolaïvna; Odes'ka derzhavna akademiya budivnitstva ta arkhitekturi. - O., -23 p.

23. Ulitskiy BE, Potapkin AA, Rudenko VI, Sakharova ID, Egorushkin YM (1967) Prostranstvennye raschety mostov. - M.: Transport. $-404 \mathrm{p}$.

24. Azizov T (2010) Effect of torsional rigidity of concrete elements with normal cracks onto special work of bridges and floorings / $\mathrm{T}$. Azizov // International science Ukrainian edition. - USA - December. - p.55-59.

25. Cowan HJ, Armstrong S (1955) Experiments on the Strength of Remforced and Prestressed Concrete Beams and of Concrete-Encased Steel Joints in Combined Bending and Torsion/ Magazine of Concrete Research,Vol.6,No.19//U.K.: London. - pp. 320.

26. Hsu TTC (1968) Torsion of Structural Concrete A Summary on Pure Torsion // Symposium on Tor sion, SP №18, AC I.- SP-18, 165-178. 